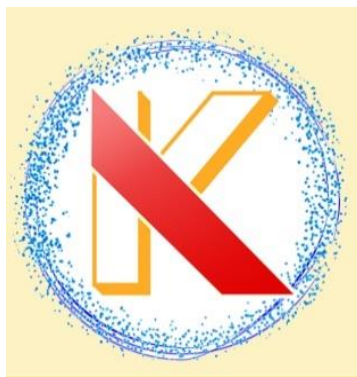

\title{
Kinerja Elektroda Platina Terlapis Enzim Butirilkholinesterase- Selulosa Asetat-Glutaraldehida untuk Deteksi Diazinon
}

\section{[Performance of Platina Electrode Coated by Butyrylcholinesterase-Cellulose Acetate-Glutaraldehyde for Diazinon Detection]}

\author{
Thamrin Azis $^{1^{*}}$ Nurhaeni $^{2}$, Caterina Bijang ${ }^{3}$, A. Nurwahida ${ }^{1}$ \\ ${ }^{1}$ Jurusan Kimia, Fakultas Matematika dan IImu Pengetahuan Alam Universitas Halu Oleo, Kendari \\ 2 Jurusan Kimia, Fakultas Matematika dan IImu Pengetahuan Alam Universitas Tadulako, Palu \\ ${ }^{3}$ Jurusan Kimia, Fakultas Matematika dan IImu Pengetahuan Alam Universitas Pattimura, Ambon \\ ${ }^{*}$ Corresponding Author: thamrinazis06@gmail.com; Telp : (085397827279)
}

\begin{abstract}
Diazinon (o, o-diethyl-o [2-isopropyl-6-methyl pyrimidynyl] phosphorotioate) is one of the organophosphate group pesticides widely used to protect cabbage plants (Brassica olarecea). Pesticide residues left in plants can bind to the cholinesterase enzyme and cause system disruption nerve. Analysis of diazinon residues in cabbage plants needs to be done to determine the level of toxicity caused. The electrochemical biosensor method as an electrochemical sensor uses a working electrode of platinum wire coated with the enzyme butybholchesteresterase (BChE) and cellulose acetate (SA) membrane and glutaraldehyde (GA) can be used for the analysis of pesticide residues. The test results of the SA electrode composition of the $10 \%$ GA $20 \%$ membrane obtained Nernst factor prices $28.1 \mu \mathrm{V} /$ decade with a measurement range of $10^{-9}-10^{-6} \mathrm{M}$, detection limit value of $1.29 \times 10^{-7} \mathrm{M}$ response time of $30-300$ seconds.
\end{abstract}

Keywords: biosensor, butylochholesterase, membrane, electrochemistry

ABSTRAK. Diazinon (o,o-diethyl-o[2-isopropil-6-metilpirimidinil]phosphorotioate) merupakan salah satu pestisida golongan organofosfat banyak digunakan untuk melindungi tanaman kubis (Brassica olarecea). Residu pestisida tertinggal pada tanaman dapat mengikat enzim cholinesterase dan menimbulkan gangguan sistem saraf. Analisis residu diazinon dalam tanaman kubis perlu dilakukan untuk mengetahui tingkat toksitas yang ditimbulkan. Metode biosensor elektrokimia sebagai sensor elektrokimia menggunakan elektroda kerja kawat platina terlapis enzim butirilkholinesterase (BChE) dan membrane selulosa asetat (SA) serta glutaraldehid (GA) dapat digunakan untuk analisis residu pestisida. Hasil uji kinerja elektroda komposisi membran SA $10 \%$ GA $20 \%$ diperoleh harga faktor Nernst $28,1 \mu \mathrm{V} /$ dekade dengan kisaran pengukuran $10^{-9}-10^{-6} \mathrm{M}$, nilai limit deteksi1,29 $\mathrm{x}$ $10^{-7} \mathrm{M}$ waktu respon $30-300$ detik.

Kata kunci: biosensor, butirilkholinesterase, membran, elektrokimia

Riwayat artikel: Diterima 6 Agustus 2020, Disetujui 18 Agustus 2020

Cara sitasi: Azis, T., Nurhaeni.,Bijang, C., \& Nurwahida, A. (2020). Kinerja Elektroda Platina Terlapis Enzim ButirilkholinesteraseSelulosa Asetat-Glutaraldehida untuk Deteksi Diazinon. KOVALEN: Jurnal Riset Kimia, 6(2): 106-111.

DOI: https://doi.org/10.22487/kovalen.2020.v6.i2.15237

\section{LATAR BELAKANG}

Pestisida merupakan senyawa organik bersifat toksik yang banyak digunakan untuk mengendalikan serangga dan hama dalam bidang pertanian (Talarico et al., 2016). Senyawa diazinon (o,o-dietil-o[2-isopropil-6metil-pirimidinil-fosforotioat) termasuk salah satu pestisida golongan organofosfat banyak 
digunakan sebagai kontrol, prefentif dan mengurangi hama pada sayuran kubis (Brassica olarecea) (Pérez-Fernández et al., 2020) . Residu pestisida yang dikonsumsi manusia dapat mengikat enzim cholinesterase, yaitu enzim yang berfungsi mengatur kerja syaraf dan menghambat asetil kolinesterase mengakibatkan akumulasi asetilkolin sehingga menimbulkan gejala sakit kepala, mual, muntah, sesak nafas, kejang otot dan dapat mengakibatkan kelumpuhan (Vimala et al., 2016)

Untuk mengetahui tingkat toksisitas dan resiko yang ditimbukan pestisida terhadap mahluk hidup dan lingkungan, maka perlu dilakukan analisis residu pestisida. Metode standar untuk deteksi organofosfat adalah kromatografi gas (KG), kromatografi cair kinerja tinggi (KCKT) dan detector spectrometer massa (Guo et al., 2019; Zhu et al., 2019). Metode ini sangatsensitif dan dapat diandalkan, tetapi memiliki kelemahan seperti, perawatan sampel yang kompleks dan menggunakan waktu lama (Zhu et al., 2019). Untuk mengatasi kelemahan tersebut, maka diperlukan metode analisis yang lebih cepat, selektif dan sederhana. Salah satu metode yang dikembangkan saat ini adalah teknik elektro kimia memiliki keunggulan dibandingkan teknik konvensional, seperti sederhana, biaya murah dan waktu analisis yang singkat (Hao et al., 2019; PérezFernández et al., 2020).

Biosensor merupakan salah satu teknik elektrokimia yang menggabungkan perangkat sensor dengan senyawa biologi dan transduser (Gupta et al., 2016; Ibrahim et al., 2017). Dalam proses kerja, senyawa aktif biologi akan berinteraksi dengan molekul sasaran dan menghasikan besaran fisik seperti panas, arus listrik, potensial listrik yang akan dimonitor oleh transduser. Beberapa penelitian menggunakan biosensor dengan berbagai jenis enzim dan transduser untuk deteksi residu petisida. Bakirhan et al. (2018) menggunakan sensor elektrokimia deteksi residu pestisida dalam makanan dengan biosensor optic menggunakan enzyme acetylcholinesteras deteksi organofosfat diperoleh limit deteksi $2,2 \times 10^{-3} \mathrm{M}$. Deteksi pestisida golongan organofosfat menggunakan biosensor konduktometri diperoleh limit deteksi diazinon 40 ppb, malation $30 \mathrm{ppb}$, klopyrofos $20 \mathrm{ppb}$ dan profenofos 40 ppm (Mulyasuryani \& Prasetyawan, 2015).

Membran selulosa asetat merupakan membrane organik yang tersusun dari bahan dasar polimer memiliki kestabilan yang baik terhadap berbagai macam zat kimia,mempunyai kekuatan mekanik yang baik dan tahan terhadap tekanan tinggi sehingga dapat menahan materi yang sangat kecil. Glutaraldehid (GA) berperan sebagai ikatan silang dan berfungsi sebagai pereaksi bifungsi antar aenzim dan selulosa asetat (Mashuni et al., 2010)

Dalam penelitian ini didesain elektroda platina terlapis enzim Butiriklonesterase (BChE) dengan bahan pendukung selulosaasetat (SA) dan glutaraldehid (GA). Hasil desain elektroda dengan dengan parameter yang optimum digunakan untuk deteksi residu diazinon dalam sayuran.

\section{METODE PENELITIAN}

\section{Bahan dan Peralatan}

Bahan yang digunakan adalah kawat perak, $\mathrm{KCl}$, kawat tembaga, kawat platina, kawat timah, enzim butirilkolinesterase (BChE) 
((EC 3.1.1.8), Selulosa Asetat (SA) (Sigma), Glutaraldehid (GA) (Sigma), asetilkolin klorida (Sigma), pestisida diazinon (Electrophorous electricus Sigma), $\mathrm{NaH}_{2} \mathrm{PO}_{4} \cdot \mathrm{H}_{2} \mathrm{O}$ (Merck), $\mathrm{Na}_{2} \mathrm{HPO}_{4} 12 \mathrm{H}_{2} \mathrm{O}$ (Merck), aseton (Merck), etanol (Merck), parafilm.

\section{Prosedur Kerja}

\section{Desain elektroda kawat terlapis (EKT)}

Elektroda dibuat dari kawat tembaga terlapis plastik berdiameter $1,5 \mathrm{~mm}$ dengan panjang $5 \mathrm{~cm}$, disambungkan dengan kawat platina berdiameter $0,4 \mathrm{~mm}$ berukuran panjang $2,5 \mathrm{~cm}$ dengan cara pateri dan masukkan ke dalam tip biru dengan posisi platina menonjol ke luar $1 \mathrm{~cm}$ dari ujung runcing. Elektroda dicelupkan kedalam bahan aktif enzim butirilkolinesterase (BChE) dan membran (selulosa asetat dan glutaraldehid). Elektroda terlapis enzim dan membran diaplikasikan ke sampel sayuran kubis untuk menentukan kadar residu diazinon

\section{Penyiapan larutan standar substrat butirilkolin klorida}

Timbang secara teliti butirilkolin klorida 1,048 gram kemudian dimasukkan ke dalam labu takar $50 \mathrm{~mL}$, selanjutnya ditambahkan larutan buffer fosfat $\mathrm{pH}$ 6,5 sebagai pelarut sampai tanda batas. Terhadap larutan ini kemudian dilakukan pengenceran sampai diperoleh larutan dengan konsentrasi 1,0 010 ${ }^{3} \mathrm{M}-1,0 \times 10^{-9} \mathrm{M}$.

\section{Pembuatan larutan standar pestisida diazinon}

Timbang secara teliti diazinon 3.0434 gram kemudian dilarutkan dengan n-heksan dalam labu ukur $100 \mathrm{~mL}$ diencerkan sampai tanda batas. Terhadap larutan ini kemudian dilakukan pengenceran pada $1,0 \times 10^{-3} \mathrm{M}$ $1,0 \times 10^{-9} \mathrm{M}$.

\section{Pembuatan larutan \\ enzim butirilkolinesterase (BChE)}

Enzim BChE dari Electrophorous electricus Sigma $24 \mathrm{mg}$ padatan dilarutkan dalam pelarut $6,32 \mathrm{ml}$ buffer fosfat $\mathrm{pH} 6,5$ dan $1 \mathrm{ml} \mathrm{KCl} \mathrm{0,1} \mathrm{M}$

\section{Pembuatan selulosa asetat (SA) $10 \%$}

Larutan selulosa asetat $10 \%$ disiapkan dengan menimbang secara teliti selulosa asetat 1,0 gram kemudian dilarutkan aseton sebanyak $10 \mathrm{~mL}$.

Pembuatan glutaraldehid (GA) $10 \%, 15 \%$ dan $20 \%$

Larutan glutaraldehid $25 \%$ yang digunakan dalam penelitian ini adalah produksi Aldrich Sigma. Selanjutnya larutan GA $10 \% ; 15 \%$ dan $20 \%$ dibuat dengan mengencerkan larutan GA $25 \%$ dengan aquades.

\section{HASIL DAN PEMBAHASAN}

Kinerja elektroda ditentukan berdasarkan pengamatan harga respon potensial masingmasing elektroda. Penentuan kinerja elektroda meliputi penentuan faktor Nernst (sensivitas), nilai limit deteksi, waktu respon, koefisien selektivitas.

\section{Faktor Nernst dan Kisaran Pengukuran}

Penentuan faktor Nernst dan kisaran pengukuran diperoleh dengan cara mengalurkan potensial $E(m V)$ terhadap konsentrasi substrat Butirilkholim kloroda ditambahkan inhibitor diazinon dengan konsentrasi $10^{-3} \mathrm{M}-10^{-9} \mathrm{M}$. Nilai teoritis faktor Nernst adalah 29,6 mV/dekade dan kurva linearitas terbaik memberikan harga $R$ mendekati satu. Hubungan antara potensial elektroda $E(\mathrm{mV})$ dengan keaktifan ion dapat dinyatakan persamaan berikut

$$
E=E^{0} \pm S \log \left(a_{A}\right)
$$


Dan hubungan dengan selektivitas ion dalam larutan dinyatakan persamaan berikut

$$
S=\frac{2,303 R T}{{ }_{Z A} F}
$$

Bila $\mathrm{E}(\mathrm{mV})$ terhadap - Log a memberikan garis linear akan memenuhi persamaan Nernst.

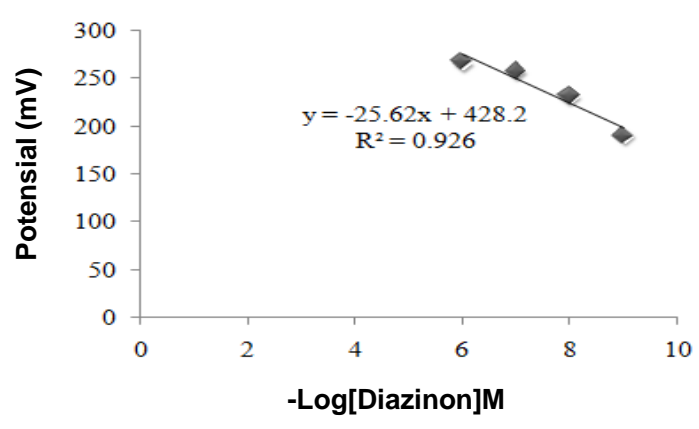

Gambar 1 Kurva potensial -Log[Diazinon] untuk komposisi membran SA $10 \%$ dan GA $10 \%$ pada konsentrasi substrat $10^{-5}$ dan konsentrasi diazinon $10^{-9}-10^{-6} \mathrm{M}$

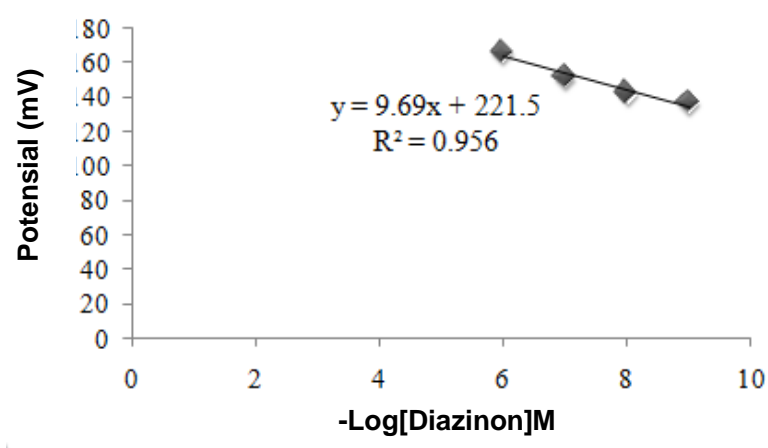

Gambar 2 Kurva potensial -Log[Diazinon] untuk komposisi membran SA $10 \%$ dan GA $15 \%$ pada konsentrasi substrat $10^{-5}$ dan konsentrasi diazinon $10^{-}-10^{-6} \mathrm{M}$

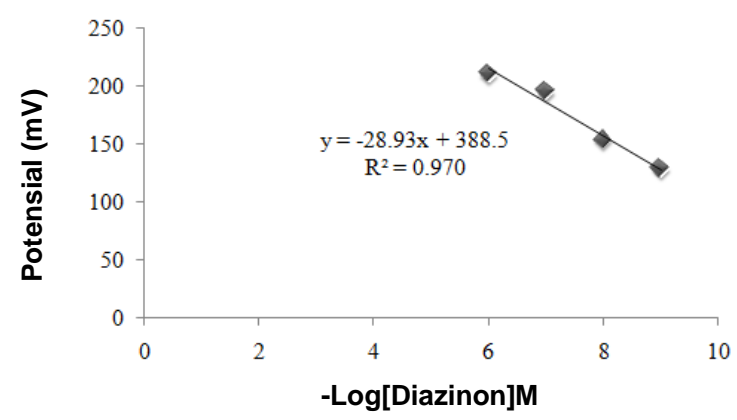

Gambar 3 Kurva potensial -Log[Diazinon] untuk komposisi membran SA $10 \%$ dan GA $20 \%$ pada konsentrasi substrat $10^{-5}$ dan konsentrasi diazinon $10^{-9}-10^{-6} \mathrm{M}$
Kepekaan dan linieritas biosensor dengan rentang konsentrasi diazinon $10^{-9} \mathrm{M}-10^{-6} \mathrm{M}$ ditampilkan pada gambar 1,2 dan 3 Hasil pengukuran potensial menggunakan potensiometer menunjukkan biosensor dengan komposisi membran SA 10\% GA 10\% (Gambar 3) memiliki kepekaan yang tinggi, yaitu 28,39 $\mathrm{mV} /$ dekade mendekati harga faktor Nernst teoritis (29,6 mV/dekade). Hasil ini menunjukkan aktivitas enzim cukup baik sebagai katalis dalam reaksi hidrolisis substrat butirilkolin klorida , sehingga memberikan respon potensial $E(m V)$ yang cukup tinggi bila dibandingkan dengan komposisi membran lain. Nilai linieritas linieritas mendekati 1 yaitu 0,970 dan harga intersepnya atau $\mathrm{E}^{0}$ adalah 388,5 . Oleh karena itu dapat disimpulkan elektroda dengan komposisi membran SA $10 \%$ GA $10 \%$ aktivitas enzim cukup baik sebagai katalis dalam reaksi hidrolisis substrat butirilkolin klorida, sehingga memberikan respon potensial $\mathrm{E}(\mathrm{mV})$ yang cukup tinggi bila dibandingkan dengan komposisi membran lain dan harga potensial $E(\mathrm{mV})$ pada daerah linier mengalami kenaikan sesuai dengan bertambahnya konsentrasi diazinon pada kisaran konsentrasi $10^{-9} \mathrm{M}-10^{-6} \mathrm{M}$, sehingga dianggap paling baik untuk pengukuran diazinon.

\section{Limit Deteksi}

Limit deteksi merupakan batas konsentrasi terendah yang dapat diukur elektroda ditentukan dengan membuat garis singgung pada fungsi linear yang Nernstian dan non Nernstian antara -log[Diazinon] dengan nilai potensial $(\mathrm{mV})$. Titik potong kedua garis diekstrapolasikan ke sumbu $\mathrm{x}$ sehingga dapat diperoleh konsentrasi limit deteksi. Hasil pengukuran limit deteksi dari 
elektroda dengan variasi komposisi membran dapat dilihat pada tabel berikut.

Tabel 1. Penentuan limit deteksi berbagai komposisi

\begin{tabular}{cccc}
\hline \multirow{2}{*}{$\begin{array}{c}\text { Tipe } \\
\text { Elektroda }\end{array}$} & \multicolumn{2}{c}{ Komposisi } & Nilai Limit \\
& SA & GA & Deteksi \\
\hline E1 & $10 \%$ & $10 \%$ & $1,51 \times 10^{-7} \mathrm{M}$ \\
E2 & $10 \%$ & $15 \%$ & $5,13 \times 10^{-7} \mathrm{M}$ \\
E3 & $10 \%$ & $20 \%$ & $1,29 \times 10^{-7} \mathrm{M}$ \\
\hline
\end{tabular}

Nilai limit deteksi menentukan kualitas suatu metode analisis, Semakin kecil limit deteksi suatu elektroda, maka semakin baik kualitas elektroda tersebut. Salah satufaktor yang menetukan kualitas limit deteksi adalah membran selulosa asetat (SA). Semakin peka suatu membrane terhadap senyawa target, maka semakin baik nilai limit deteksi yang akan diperoleh. Hasil penentuan limit deteksi berbagai komposisi membrane dapat dilihat dalam Tabel1. Hasil ektrapolasi pembacaan elektroda SA $10 \%$ GA $20 \%$ terhadap sumbu $x$ dengan rentang konsentrasi diazinon $10^{-9} \mathrm{M}-10^{-3} \mathrm{M}$ menghasilkan limit deteksi terendah1,29 x 10 $0^{-7} \mathrm{M}$ (Tabel 1).

\section{Waktu Respon}

Waktu respon adalah waktu yang diperlukan suatu biosensor untuk mencapai potensial yang konstan. Hal ini disebabkan telah terjadinya kesetimbangan reaksi yang terjadi pada membran elektroda dengan larutan sampel.

Semakin sensitif suatu elektroda semakin cepat waktu responnya. Faktor respon dipengaruhi oleh beberapa faktor, seperti kestabilan membran, konsentrasi sampel, temperatur sampel, adanya ion-ion pengganggu dan putaran stirrer. Profil waktur espons deteksi diazinon dengan variasi komposisi membran SA/GA dengan metode potensiometri terlihat pada Gambar 4.

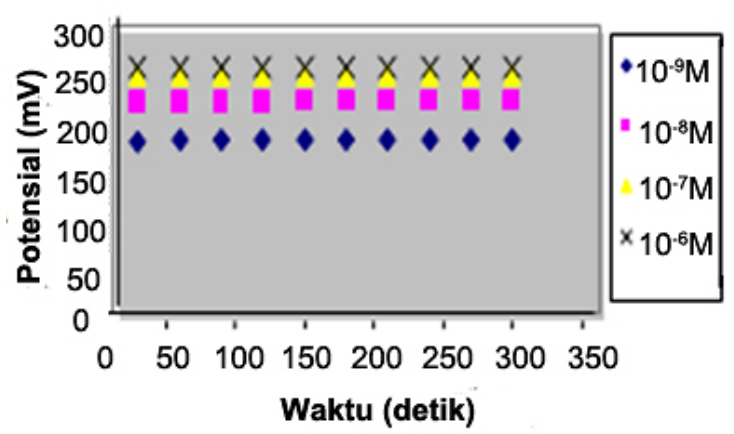

(a)

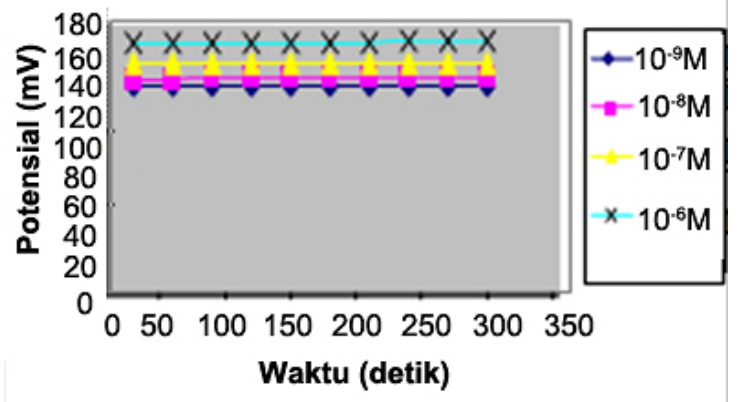

(b)

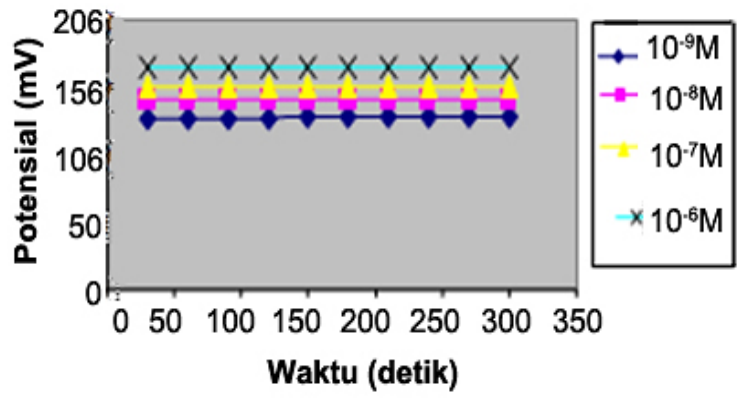

(c)

Gambar 4. Waktu respon biosensor diazinon dengan komposisi membran (a) SA $10 \%$ GA10 $\%$, (b) SA $10 \%$ GA $15 \%$, dan (c) SA $10 \%$ GA $20 \%$ pada konsentrasi substrat $10^{-5} \mathrm{M}$

Tabel 2. Kinerja elektroda enzim butirilkolinesterase

\begin{tabular}{lccc}
\hline \multirow{2}{*}{\multicolumn{1}{c}{ Kinerja }} & \multicolumn{3}{c}{ Tipe elektroda enzim } \\
Elektroda & E1 & E2 & E3 \\
\cline { 2 - 4 } & (SA10\% & (SA10\% & $(\mathrm{SA} 10 \%$ \\
& $\mathrm{GA} 10 \%)$ & $\mathrm{GA} 15 \%)$ & $\mathrm{GA} 20 \%)$ \\
\hline $\mathrm{E} 0(\mathrm{mV})$ & 428,2 & 221,5 & 388,5 \\
$\mathrm{~S}$ & 25,62 & 6,96 & 28,93 \\
$\mathrm{R}^{2}$ & 0,926 & 0,956 & 0,970 \\
Limit deteksi (M) & $1,51 \times 10^{-7}$ & $5,13 \times 10^{-7}$ & $1,29 \times 10^{-7}$ \\
Waktu respon & $30-300$ & $30-300$ & $30-300$ \\
\hline
\end{tabular}




\section{KESIMPULAN}

Berdasarkan hasil penelitian yang telah dilakukan, maka dapat diambil kesimpulan, bahwa elektroda komposisi membran selulosa asetat (SA) $10 \%$ dan glutaradehid (GA) $20 \%$ memiliki kinerja lebih baik dibanding elektroda komposisi membran SA $10 \%$ GA 5,0\% dan SA $10 \%$ GA $15 \%$. Hasil kinerja elektroda SA $10 \%$ GA $10 \%$ meliputi faktor Nernst (sensivitas) 28,39 $\mathrm{mV} /$ dekade pada rentang pengukuran pada kisaran konsentrasi $10^{-9} \mathrm{M}-10^{-6} \mathrm{M}$ baik untuk pengukuran diazinon. Limit deteksi dengan harga $1,29 \times 10^{-7} \mathrm{M}$ merupakan limit deteksi terendah dengan rentang konsentrasi diazinon $10^{-9} \mathrm{M}-10^{-3} \mathrm{M}$ dan waktu respon 30 detik 300 detik.

\section{DAFTAR PUSTAKA}

Bakirhan, Nurgul K, Bengi Uslu, and Sibel A Ozkan. (2018). The Detection of Pesticide in Foods Using Electrochemical Sensors. In Food Safety and Preservation. Pp. 91-141: Elsevier.

Guo, Jiagang, et al. (2019). Analysis of Multiple Pesticide Residues In Polyphenol-Rich Agricultural Products by UPLC-MS/MS Using a Modified QuEChERS Extraction and Dilution Method. Food chemistry 274:452-459.

Gupta, Deepali, Balwinder Singh, and Harpreet Singh. (2016). Design and Development of Pesticide Residue Detection System using EC and $\mathrm{pH}$ Sensor. International Journal Engineering and Manufacturing (IJEM) 2:10-17.

Hao, Rui, Zhuoyu Peng, and Bo Zhang. (2019) Single-Molecule Fluorescence Microscopy for Probing the Electrochemical Interface. ACS omega 5(1):89-97.

Ibrahim, AG, OD Oyedum, and OB wojowogbe. (2017). Design

Description of a Stand-Alone, AutoFrequency Ultrasonic Brand of Weaver Bird Pest Control Device for Field
Applications. International Journal of Engineering and Manufacturing 7(5):1.

Mashuni, Mashuni, et al. (2010). Determination of Carbamate Pesticides Using a Biosensor Based on Enzyme Acetylcholinesterase and Cholin Oxidase $\mathrm{n}$ Platinum Electrode. Indonesian Journal of Chemistry 10(3):290-294.

Mulyasuryani, Ani, and Sasangka Prasetyawan. (2015).

Organophosphate Hydrolase in Conductometric Biosensor for The Detection of Organophosphate Pesticides. Analytical chemistry insights 10:ACI. S30656.

Pérez-Fernández, Beatriz, Agustín CostaGarcía, and Alfredo de la Escosura Muñiz. (2020). Electrochemical (Bio) Sensors for Pesticides Detection Using Screen-Printed Electrodes. Biosensors 10(4):32.

Talarico, Daria, et al. (2016). Screen Printed Electrode Modified With Carbon Black and Chitosan: A Novel Platform for Acetylcholinesterase Biosensor Development. Analytical and bioanalytical chemistry 408(26):72997309.

Vimala, V, SK Clarke, and S Urvinder Kaur. (2016). Pesticides Detection Using Acetylcholinesterase Nanobiosensor. Biosens J 5(133): 2 .

Zhu, Bingqi, et al. (2019). Simultaneous Determination of 131 Pesticides in Tea by On-line GPC-GC-MS/MS Using Graphitized Multi-Walled Carbon Nanotubes as Dispersive Solid Phase Extraction Sorbent. Food chemistry 276:202-208. 